Article

\title{
Domestic Risk Factors for Atopic and Non-Atopic Asthma in First Nations Children Living in Saskatchewan, Canada
}

\author{
Donna C. Rennie ${ }^{1,2, *}$, Chandima P. Karunanayake ${ }^{2, *}$, Josh A. Lawson ${ }^{3}$, Shelley Kirychuk ${ }^{3}$, \\ Kathleen McMullin ${ }^{4}$, Sylvia Abonyi ${ }^{4}$, Jeremy Seeseequasis ${ }^{5}$, Judith MacDonald ${ }^{6}$, \\ James A. Dosman ${ }^{2,3}$ and Punam Pahwa ${ }^{2,4}$ \\ 1 College of Nursing, University of Saskatchewan, 107 Wiggins Road, Saskatoon, SK S7N 2Z4, Canada \\ 2 Canadian Centre for Health and Safety in Agriculture, University of Saskatchewan, 104 Clinic Place, \\ Saskatoon, SK S7N 2Z4, Canada; james.dosman@usask.ca (J.A.D.); pup165@mail.usask.ca (P.P.) \\ 3 Department of Medicine, College of Medicine, University of Saskatchewan, 103 Hospital Drive, \\ Saskatoon, SK S7N 0X8, Canada; jal226@mail.usask.ca (J.A.L.); shelley.kirychuk@usask.ca (S.K.) \\ 4 Department of Community Health and Epidemiology, College of Medicine, University of Saskatchewan, \\ 104 Clinic Place, Saskatoon, SK S7N 2Z4, Canada; kathleen.mcmullin@usask.ca (K.M.); \\ sya277@mail.usask.ca (S.A.) \\ 5 Willow Cree Health Centre, Beardy's and Okemasis First Nation, P.O. Box 96, \\ Duck Lake, SK S0K 1J0, Canada; jseeseequasis@beardysband.com \\ 6 William Charles Health Centre, Montreal Lake Cree Nation, P.O. Box 240, \\ Montreal Lake, SK S0J 1Y0, Canada; judithlynmacdonald@hotmail.com \\ * Correspondence: donna.rennie@usask.ca (D.C.R.); cpk646@mail.usask.ca (C.P.K.); \\ Tel.: +1-306-966-7886 (D.C.R.); +1-306-966-1647 (C.P.K.)
}

Received: 27 February 2020; Accepted: 21 April 2020; Published: 27 April 2020

\begin{abstract}
Both allergic and non-allergic asthma phenotypes are thought to vary by specific housing and other indoor environmental conditions. This study evaluated risk factors for allergic asthma phenotypes in First Nation children, an understudied Canadian population with recognized increased respiratory morbidity. We conducted a cross-sectional survey with a clinical component to assess the respiratory health of 351 school-age children living on two rural reserve communities. Asthma was defined as parental report of physician diagnosed asthma or a report of wheeze in the past 12 months. Atopy was determined by a $\geq 3$-mm wheal response to any of six respiratory allergens upon skin prick testing (SPT). Important domestic and personal characteristics evaluated included damp housing conditions, household heating, respiratory infections and passive smoking exposure. Asthma and atopy prevalence were $17.4 \%$ and $17.1 \%$, respectively. Of those with asthma, $21.1 \%$ were atopic. We performed multivariate multinomial logistic regression modelling with three outcomes: non-atopic asthma, atopic asthma and no asthma for 280 children who underwent SPT. After adjusting for potential confounders, children with atopic asthma were more likely to be obese and to live in homes with either damage due to dampness $(p<0.05)$ or signs of mildew/mold $(p=0.06)$. Both natural gas home heating and a history of respiratory related infections were associated with non-atopic asthma $(p<0.01)$. Domestic risk factors for asthma appear to vary by atopic status in First Nations children. Determining asthma phenotypes could be useful in environmental management of asthma in this population.
\end{abstract}

Keywords: Atopic asthma; non-atopic asthma; domestic environments; damp housing; Aboriginal 


\section{Introduction}

Aboriginal peoples, including First Nations, Inuit and Metis groups, represent $2.6 \%$ of the Canadian population and, of these, $60.8 \%$ are First Nation [1]. Unlike their non-Aboriginal counterparts, Aboriginal children make up a disproportionally larger percentage of their population $(29.0 \%$ versus $16.5 \%$ ) for non-Aboriginal children [1]. Respiratory disease, including asthma, is a major cause of emergency room visits and hospitalization in First Nations and other Aboriginal children [2,3]. Although the burden of asthma is higher in Aboriginal child populations compared to same age and sex non-Aboriginal populations, the prevalence of asthma (9.5 to 14.6\%) is similar [4-6], with household factors playing a role in disease manifestation $[4,7,8]$. While respiratory disease, including asthma, is a major cause of illness for Canadian Aboriginal children [7], there is limited understanding of the role of atopy in asthma prevalence [6,9] within this population.

Major environmental factors known to be associated with childhood asthma can be allergenic or non-allergenic in origin [10]. The allergic form of asthma is triggered by contact with specific environmental aeroallergens resulting in an adaptive Thelper cell (TH2 high) immune response with increased eosinophilia. Conversely, the non-allergic form is characterized by a low TH2 (TH2low) adaptive immunity, primarily in response to certain microbial agents including viruses, with resulting neutrophilia $[10,11]$. While a history of parental atopic disease is associated with both non-atopic and atopic childhood phenotypes of asthma [12], environmental exposures seem to vary by asthma allergic phenotype $[12,13]$.

Two recent meta-analyses concluded that there was approximately a 30-50\% increased risk of childhood asthma with reported damp housing [14,15]. Dampness, moisture and mold are prevailing conditions in the homes located on the rural First Nation reserves [16-18]. National studies examining the health of children on reserves consistently report that homes requiring major repairs are associated with respiratory outcomes including asthma, although the potential contributing features of these homes, such as dampness and mold, have not been explored [4,6]. To date, there is limited understanding of how dampness and other housing conditions of First Nation children's homes may contribute to increased asthma and specifically, to either non-atopic and atopic asthma. The purpose of this investigation was to assess the importance of particular housing conditions for asthma risk among First Nations children living on two rural reserve communities, with specific evaluation by non-atopic and atopic status.

\section{Materials and Methods}

The First Nations Lung Health Study is a longitudinal study of the respiratory health of persons six years and older living in either a Plains Cree or Woodland Cree First Nation community located in rural Saskatchewan, Canada. This analysis evaluates data from the baseline cross-sectional study conducted in 2013 for children 6-17 years of age. Ethical approval for the children's study was received from the University of Saskatchewan Biomedical Ethics Review Board (Bio Certificate \#13-27).

The detailed research protocol used for the children's study has been previously reported [19]. School officials approved the study and surveys. We distributed questionnaires to parents through community schools and a neighboring school of one community where the enrollment primarily consisted of children from the study community. Parental consent and child assent forms for clinical testing accompanied the questionnaires. Clinical assessments conducted at the schools included anthropometric measurements and skin prick testing (SPT) to local aeroallergens. Parents returned questionnaires and consent/assents to the school for collection by the research team. A \$5.00 (CDN) incentive was provided to those returning questionnaires.

\subsection{Asthma Phenotypes}

Asthma was defined by questionnaire as either a report of physician diagnosed asthma or wheeze in the past 12 months. Atopy was assessed by SPT to six common standardized inhalant 
allergens: combined $d$ farina and $d$ pteronyssinus (house dust mite mixed, (HDM mixed)), Cladosporium, Alternaria, Aspergillus, felis $d$ (cat), and mixed grasses (ALK-Abello Pharmaceuticals, Inc, Mississauga $\mathrm{ON}$ ). In addition, negative (saline) and positive (histamine) controls were used. Atopic was defined as a positive SPT prick test to any allergen with a wheal of $\geq 3 \mathrm{~mm}$ compared to the negative control [20]. Notably, four of the six allergens chosen (HDM, cat, grass, and Alternaria alternata) are known to account for approximately $94 \%$ of atopy in young children [21]. The asthma phenotype was defined by atopic status and was categorized into three groups: atopic asthma, non-atopic asthma, and no asthma.

\subsection{Moisture/Mold and Other Housing Conditions}

We identified damage caused by dampness (damp damage) by the question: "Does your home have any damage caused by dampness (e.g., wet spots on walls, floors)? (yes/no)". Mold/mildew was determined by the question: "Are there signs of mold or mildew in any living areas of your home? (yes/no)" and home dampness by a question that identified water or dampness in the home in the past 12 months due to broken pipes, leaks, heavy rain or flooding (yes/no). Other dichotomized (yes/no) variables included having a cat or dog in the home and environmental tobacco smoke (ETS) exposure (child smoked or smoking occurred in the home). A crowding index was calculated as a ratio of number of individuals in the home to the number of rooms excluding bathrooms and hallways. We also assessed use (yes/no) of a dehumidifier, humidifier, air conditioner, air filter in the home and the type of home heating (natural gas or other).

\subsection{Personal Characteristics}

Body mass index (BMI) was calculated from measured height and weight using the standard BMI formula (weight $(\mathrm{Kg}) /$ height $(\mathrm{cm})^{2}$ ). Children were then classified as obese, overweight and normal/underweight according to age and sex-standardized BMI [22]. Height was measured against a wall in centimeters $(\mathrm{cm})$ using a fixed tape measure. Weight was measured in kilograms $(\mathrm{Kg})$ using a spring scale. Children performed both procedures wearing indoor clothing and stockinged feet.

Other variables assessed by questionnaire included parental education $(<$ Grade $12, \geq$ Grade 12) and a parental history any of the following atopic conditions: asthma, allergy, eczema or hay fever. Respiratory-related infections (RRI) were assessed as a history of any of the following: croup, bronchitis, pneumonia, tonsillitis, ear infection and/or the use of antibiotics in the past 12 months to treat a respiratory problem (Yes/No).

\subsection{Statistical Analysis}

Data were analyzed for the 280 children who underwent SPT. Univariate associations between the three outcome groups (atopic asthma, non-atopic asthma, and no asthma) and household and personal characteristics were assessed by $\chi^{2}$ test for proportions and one-way analysis of variance for continuous data. There were moderately significant correlations $(p<0.05)$ observed between damp damage, damp housing, visible mold and mildew. Because of this and the strong conceptual relationships between the three variables, we analyzed each of these dampness indicators separately. Multinomial logistic regression analyses were conducted to assess relationships between different measures of dampness and mold and asthma phenotypes. The strength of associations were assessed by the odds ratios (OR) and $95 \%$ confidence intervals (CI). Potential effect modifiers significant at the $p<0.10$ level or those known to be frequently associated with asthma in previous studies were included. We used SPSS Version 24 (IBM SPSS Statistics for Windows. Armonk, NY, USA: IBM Corp., 2017) for all analyses.

\section{Results}

There were 351 school-age children who completed the survey for a response rate of $57.7 \%$. The mean age of students was $10.9 \pm 3.1$ years and more girls $(55.0 \%)$ than boys participated in the study. Asthma prevalence did not differ between the two communities and was significantly higher in 
boys $(21.8 \%)$ than in girls $(13.4 \%, p<0.05)$. In total, there were 47 children $(13.4 \%)$ with a report of wheeze in the past 12 months and $61(17.4 \%)$ children who had a diagnosis of asthma only. Of those with asthma, $36.1 \%$ reported wheezing in the past 12 months.

We found no differences in demographic factors or housing characteristics between those who underwent SPT and those who did not (data not presented). Of the 280 children who underwent SPT, $48(17.1 \%)$ were atopic. Of those with a positive SPT, $23(47.9 \%)$ were sensitized to HDM mixed and $19(39.6 \%)$ to cat dander. The proportion of children sensitized to any mold was $12.5 \%$. Of those undergoing SPT, $71(25.4 \%)$ had asthma. Atopy was identified in 15 (21.1\%) children with asthma and in $33(15.8 \%)$ children with no asthma. Atopy and asthma status did not differ by community.

Table 1 presents the personal and housing characteristics of children by asthma phenotype. Within asthma groups, the prevalence of obesity was almost twice as high in the atopic asthma group compared to the non-atopic asthma group and more than double of that observed in the non-asthma group. Reported parental atopy was similar in the atopic and non-atopic asthma groups and higher than what we observed in children with no asthma. There were $58 \%$ of the children with a history of RRIs and the prevalence of such infections was highest in the non-atopic asthma group $(p<0.001)$.

Table 1. Personal and housing characteristics by asthma phenotype for 280 First Nation children.

\begin{tabular}{|c|c|c|c|c|c|}
\hline Variable & $\begin{array}{c}\text { Total } \\
n=280\end{array}$ & $\begin{array}{l}\text { Atopic Asthma } \\
\quad n=15\end{array}$ & $\begin{array}{c}\text { Non-Atopic } \\
\text { Asthma } \\
n=56\end{array}$ & $\begin{array}{c}\text { No Asthma } \\
n=209\end{array}$ & $p$ Value \\
\hline & Mean \pm SD & Mean \pm SD & Mean \pm SD & Mean \pm SD & \\
\hline Age in years & $10.9 \pm 3.1$ & $12.4 \pm 3.1$ & $11.0 \pm 3.0$ & $10.8 \pm 3.1$ & 0.13 \\
\hline Crowding index & $\begin{array}{c}1.6 \pm 0.7 \\
n(\%)\end{array}$ & $\begin{array}{c}1.5 \pm 0.5 \\
n(\%)\end{array}$ & $\begin{array}{c}1.6 \pm 0.6 \\
n(\%)\end{array}$ & $\begin{array}{c}1.6 \pm 0.7 \\
n(\%)\end{array}$ & 0.76 \\
\hline \multicolumn{6}{|l|}{ Sex } \\
\hline Male & $126(45.0)$ & $10(66.7)$ & $30(53.6)$ & $86(41.1)$ & 0.06 \\
\hline Female & $154(55.0)$ & $5(33.7)$ & $26(46.4)$ & $123(58.9)$ & \\
\hline \multicolumn{6}{|l|}{ Body mass index } \\
\hline Obese & $61(22.0)$ & 7 (46.7) & $14(25.0)$ & $40(19.4)$ & 0.12 \\
\hline Overweight & $87(31.4)$ & $4(26.7)$ & $19(33.9)$ & $64(31.1)$ & \\
\hline Normal & $129(46.6)$ & $4(26.7)$ & $23(41.1)$ & $102(49.5)$ & \\
\hline \multicolumn{6}{|l|}{$\begin{array}{l}\text { Respiratory related } \\
\text { infections }\end{array}$} \\
\hline Yes & $165(58.9)$ & $8(53.3)$ & $46(82.1)$ & $111(53.1)$ & $<0.001$ \\
\hline No & $115(41.1)$ & $7(46.7)$ & $10(17.9)$ & $98(46.9)$ & \\
\hline \multicolumn{6}{|l|}{ Passive smoking } \\
\hline Yes & $154(55.0)$ & $10(66.7)$ & $36(64.3)$ & $108(51.7)$ & 0.16 \\
\hline No & $126(45.0)$ & $5(33.3)$ & $20(35.7)$ & $101(48.3)$ & \\
\hline \multicolumn{6}{|l|}{$\begin{array}{l}\text { Parental history of } \\
\text { allergic conditions }\end{array}$} \\
\hline Yes & $112(40.0)$ & $8(53.3)$ & $29(51.8)$ & $75(35.9)$ & 0.05 \\
\hline $\mathrm{No}$ & $168(60.0)$ & $7(46.7)$ & $27(48.2)$ & $134(64.1)$ & \\
\hline \multicolumn{6}{|l|}{ Parental education } \\
\hline$<$ Grade 12 & $146(52.1)$ & $5(33.3)$ & $26(46.4)$ & $115(55.0)$ & 0.17 \\
\hline $\begin{array}{l}\geq \text { Grade } 12 \\
\text { Fuel type }\end{array}$ & $134(47.9)$ & $10(66.7)$ & 30 (53.6) & $94(45.0)$ & \\
\hline Natural gas & $229(81.8)$ & $13(86.7)$ & $52(92.9)$ & $164(78.5)$ & 0.04 \\
\hline Other & $51(18.2)$ & $2(13.3)$ & $4(7.1)$ & $45(21.5)$ & \\
\hline \multicolumn{6}{|l|}{$\begin{array}{l}\text { Air conditioner in } \\
\text { home }\end{array}$} \\
\hline Yes & $90(32.1)$ & $5(33.3)$ & $18(32.1)$ & $67(32.1)$ & 0.99 \\
\hline No & $190(67.9)$ & $10(66.7)$ & $38(67.9)$ & $142(67.9)$ & \\
\hline \multicolumn{6}{|l|}{ Air filter in home } \\
\hline Yes & $120(42.9)$ & $3(20.0)$ & $20(35.7)$ & $97(46.4)$ & 0.07 \\
\hline No & $160(57.1)$ & $12(80.0)$ & $36(64.3)$ & $112(53.6)$ & \\
\hline
\end{tabular}


Table 1. Cont.

\begin{tabular}{|c|c|c|c|c|c|}
\hline Variable & $\begin{array}{c}\text { Total } \\
n=280\end{array}$ & $\begin{array}{l}\text { Atopic Asthma } \\
\qquad n=15\end{array}$ & $\begin{array}{l}\text { Non-Atopic } \\
\text { Asthma } \\
n=56\end{array}$ & $\begin{array}{c}\text { No Asthma } \\
n=209\end{array}$ & $p$ Value \# \\
\hline \multicolumn{6}{|c|}{ Humidifier in home } \\
\hline Yes & $37(13.2)$ & $1(6.7)$ & $10(17.9)$ & $26(12.4)$ & 0.42 \\
\hline No & $243(86.3)$ & $14(93.3)$ & $46(82.1)$ & $183(87.6)$ & \\
\hline \multicolumn{6}{|c|}{ Dehumidifier in home } \\
\hline Yes & $25(8.9)$ & $4(26.7)$ & $5(8.9)$ & $16(7.7)$ & 0.05 \\
\hline No & $255(91.1)$ & $11(73.3)$ & $51(91.1)$ & $193(92.3)$ & \\
\hline \multicolumn{6}{|c|}{$\begin{array}{l}\text { Wood fireplace in } \\
\text { home }\end{array}$} \\
\hline Yes & $8(2.9)$ & $1(6.7)$ & $1(1.8)$ & $6(2.9)$ & 0.60 \\
\hline No & $272(97.1)$ & $14(93.3)$ & $55(98.2)$ & $203(97.1)$ & \\
\hline \multicolumn{6}{|c|}{ Pet cat/dog in home } \\
\hline Yes & 137 (48.9) & $7(46.7)$ & $28(50.0)$ & $102(48.8)$ & 0.97 \\
\hline No & $143(51.1)$ & $8(53.3)$ & $28(50.0)$ & $107(51.2)$ & \\
\hline \multicolumn{6}{|c|}{$\begin{array}{c}\text { Damage caused by } \\
\text { dampness }\end{array}$} \\
\hline Yes & $113(40.4)$ & $11(73.3)$ & $25(44.6)$ & $77(36.8)$ & 0.02 \\
\hline No & $167(59.6)$ & $4(26.7)$ & $31(55.4)$ & $132(63.2)$ & \\
\hline \multicolumn{6}{|c|}{$\begin{array}{l}\text { Signs of mold or } \\
\text { mildew in home }\end{array}$} \\
\hline Yes & $121(43.2)$ & $11(73.3)$ & $23(41.1)$ & $87(41.6)$ & 0.05 \\
\hline No & $159(56.8)$ & $4(26.7)$ & $33(58.9)$ & $122(58.4)$ & \\
\hline \multicolumn{6}{|c|}{$\begin{array}{l}\text { Home dampness past } \\
12 \text { months }\end{array}$} \\
\hline Yes & $152(54.3)$ & $11(73.3)$ & $34(60.7)$ & 107 (51.2) & 0.14 \\
\hline No & $128(45.7)$ & $4(26.7)$ & $22(39.3)$ & $102(48.8)$ & \\
\hline
\end{tabular}

\# For the categorical variables, chi squared test for proportions $p$ value reported and for the continuous variables, F test $p$ value reported.

Household dampness varied from $40.4 \%$ for damage due to dampness to $54.3 \%$ for recent evidence of water or leaks in the home (Table 1). Of the three outcome groups, children with atopic asthma were most likely to live in homes with damp damage or in those with signs of mold/mildew. The use of air quality measures in homes was infrequent and did not differ by group. While natural gas use was the most common form of heating, its use was highest in homes of children with non-atopic asthma $(p<0.01)$. ETS exposure was prevalent with $55 \%$ of children exposed. This was higher in the non-atopic asthma group. Notably, $88 \%$ of children had at least one parent who smoked. Table 2 presents the univariate odds ratios and $95 \%$ CI for important household and personal factors considered in the multivariate analyses.

The results of the adjusted multinomial logistic regression models for reports of dampness or mold in the home by atopic status are presented in Table 3 (Models 1, 2,3). Compared to children with no asthma and consistent with the findings from the univariate regression, children with atopic asthma were significantly more likely to live in homes with damage due to dampness (Model 1). As shown in Model 2, there continued to be a borderline statistical association between a report of visible mold or mildew in the home and atopic asthma $(p=0.06)$. A report of a home dampness event in the past 12 months was not associated with atopic or non-atopic asthma. While obesity was associated with an increased risk of atopic asthma in all models, natural gas heating and a history of an RRI were consistently associated with non-atopic asthma in all models. 
Table 2. Univariate multinomial logistic regression analyses (odds ratio (OR) and 95\% confidence intervals (CI)) of variables added to the multivariate analyses assessing risk factors for atopic and non-atopic asthma (referent: no asthma) for 280 First Nation children.

\begin{tabular}{|c|c|c|}
\hline Variable (Referent) & $\begin{array}{c}\text { Atopic Asthma } \\
n=15 \\
\text { OR }_{\text {unadjusted }}(95 \% \mathrm{CI})\end{array}$ & $\begin{array}{l}\text { Non-Atopic Asthma } \\
\quad n=56 \\
\text { OR }_{\text {unadjusted }}(95 \% \mathrm{CI})\end{array}$ \\
\hline Age, in years & $1.2(1.00,1.41) *$ & $1.0(0.93,1.13)$ \\
\hline \multicolumn{3}{|l|}{ Crowding index } \\
\hline Sex (Female) & $2.9(0.94,8.66)$ & $1.7(0.91,2.99)$ \\
\hline \multicolumn{3}{|l|}{ Body Mass index (Normal/underweight) } \\
\hline Obese & $4.5(1.24,16.08) *$ & $1.6(0.73,3.31)$ \\
\hline Overweight & $1.6(0.38,6.60)$ & $1.3(0.66,2.61)$ \\
\hline Respiratory related infections (No) & $1.0(0.35,2.88)$ & $4.1(1.95,8.48)^{* *}$ \\
\hline Passive smoking (No) & $1.9(0.62,5.66)$ & $1.7(0.91,3.09)$ \\
\hline \multicolumn{3}{|l|}{ Parental education ( $\geq$ Grade 12 ) } \\
\hline Less than grade 12 & $0.4(0.13,1.24)$ & $0.7(0.39,1.28)$ \\
\hline \multicolumn{3}{|l|}{ Fuel type (Other) } \\
\hline Natural gas & $1.8(0.39,8.19)$ & $3.6(1.22,10.39) *$ \\
\hline Damage caused by dampness (No) & $4.7(1.45,15.32) *$ & $1.4(0.76,2.51)$ \\
\hline Signs of mold or mildew in home (No) & $3.9(1.19,12.51) *$ & $1.0(0.54,1.78)$ \\
\hline Home dampness past 12 months (No) & $2.6(0.81,8.50)$ & $1.5(0.81,2.69)$ \\
\hline
\end{tabular}

$$
{ }^{*} p<0.05 ;{ }^{* *} p<0.01 \text {. }
$$

Table 3. Multivariate multinomial logistic regression model results (odds ratio (OR) and 95\% confidence intervals (CI)) assessing damp housing characteristics for atopic and non-atopic asthma (reference to no asthma).

\begin{tabular}{|c|c|c|}
\hline Variable (Referent) & $\begin{array}{c}\text { Atopic Asthma } \\
\text { OR }_{\text {adjusted }}(95 \% \text { CI })\end{array}$ & $\begin{array}{l}\text { Non-Atopic Asthma } \\
\text { OR }_{\text {adjusted }}(95 \% \mathrm{CI})\end{array}$ \\
\hline \multicolumn{3}{|l|}{ Model $1^{\dagger}$ (Damage Caused by Dampness) } \\
\hline \multicolumn{3}{|l|}{ Body Mass Index (Normal/underweight) } \\
\hline Obese & $5.9(1.31,26.34) *$ & $1.6(0.67,3.65)$ \\
\hline Overweight & $1.5(0.32,6.96)$ & $1.1(0.51,2.22)$ \\
\hline Ever had infections (No) & $0.6(0.17,2.02)$ & $3.6(1.65,7.65)^{* *}$ \\
\hline Passive smoking (No) & $1.7(0.38,5.69)$ & $1.8(0.90,3.68)^{* * *}$ \\
\hline \multicolumn{3}{|l|}{ Fuel type (Other/combine fuel) } \\
\hline Natural gas & $2.8(0.55,14.38)$ & $4.5(1.44,14.06) *$ \\
\hline Damage caused by dampness (No) & $5.5(1.43,20.99) *$ & $1.2(0.60,2.38)$ \\
\hline \multicolumn{3}{|l|}{ Model $2^{\dagger}$ (Signs of Mold or Mildew) } \\
\hline \multicolumn{3}{|l|}{ Body Mass Index (Normal/underweight) } \\
\hline Obese & $6.8(1.54,29.91)^{*}$ & $1.6(0.69,3.75)$ \\
\hline Overweight & $1.6(0.36,7.42)$ & $1.1(0.54,2.32)$ \\
\hline Ever had infections (No) & $0.7(0.19,2.15)$ & $3.7(1.73,8.03)^{* *}$ \\
\hline Passive smoking (No) & $1.7(0.47,6.38)$ & $2.0(0.98,3.89)^{* * *}$ \\
\hline \multicolumn{3}{|l|}{ Fuel type (Other) } \\
\hline Natural gas & $2.6(0.50,13.53)$ & $4.3(1.37,13.26)^{* *}$ \\
\hline Signs of mold or mildew in home (No) & $3.6(0.99,12.91)^{* * *}$ & $0.8(0.41,1.55)$ \\
\hline \multicolumn{3}{|l|}{ Model $3^{+}$(Home Dampness Past 12 Months) } \\
\hline \multicolumn{3}{|l|}{ Body Mass Index (Normal/underweight) } \\
\hline Obese & $8.9(2.00,39.11)^{* *}$ & $1.6(0.70,3.71)$ \\
\hline Overweight & $1.9(0.41,8.46)$ & $1.1(0.51,2.22)$ \\
\hline Ever had infections (No) & $0.6(0.19,2.14)$ & $3.5(1.63,7.53)^{* * *}$ \\
\hline Passive smoking (No) & $1.9(0.50,6.84)$ & $1.8(0.88,3.56)$ \\
\hline \multicolumn{3}{|l|}{ Fuel type (Other) } \\
\hline Natural gas & $3.0(0.59,14.78)$ & $4.6(1.48,14.46)^{* *}$ \\
\hline Home dampness past 12 months (No) & $3.4(0.92,12.89) * * *$ & $1.5(0.75,2.81)$ \\
\hline
\end{tabular}

${ }^{*} p<0.05 ;{ }^{* *} p<0.01 ;{ }^{* * *}$ borderline $(p<0.10){ }^{\dagger}$ adjusted for age, sex, crowding index and parental education. 


\section{Discussion}

In this study, reports of both damage to the home caused by dampness and the presence of visible mold or mildew in the home were associated with atopic asthma but not with non-atopic asthma. There were clear differences in associations by phenotype for other risk factors as well. While obesity was associated with atopic asthma, natural gas heating in the home and RRIs were associated with non-atopic asthma.

Asthma prevalence in this study at $17.4 \%$ (with $95 \%$ CI: $13.4-21.3 \%$ ) is similar to that reported regionally in rural, non-Aboriginal child populations (14.7-18.9\%) $[13,19,23,24]$. While atopy measured by SPT at $17.8 \%$ was comparatively lower $(19.4-22.4 \%)[24,25]$. Our data show that asthma prevalence appears to be higher than what has been previously reported in other Canadian First Nation child populations. Using data from the 2003 Regional First Nations Survey, Senthilselvan et al. [6] reported asthma in Canadian First Nations children five to 11 years old living on reserves to be $15.6 \%$. Chang et al. noted an asthma prevalence of $14.3 \%$ in off-reserve First Nations children aged 6-14 years participating in the 2006 Aboriginal Peoples Survey [8]. A comparable asthma prevalence of approximately $18 \%$ was observed for American Indian/Alaskan Native children participating in the National Health Interview Survey 2001-2005 [26]. The increase in asthma prevalence in the current study is modest and may be due to use of different asthma definitions and the variability of assessment strategies used between studies. However, the generally poor housing conditions observed in the reserve communities and the high prevalence of smoking found in homes (52.7\% of all study homes) could also contribute to higher asthma prevalence seen in the current study.

While the burden associated with asthma was not a primary focus of this study, two potential measures of health burden within the study population including school absenteeism for three days or more due to chest illness and previous hospitalization for a chest illness were examined retrospectively and it appears that children with asthma have increased morbidity. When compared to children without asthma, children with asthma were proportionally more likely to be absent from school $(p<0.001)$ because of a chest illness or to require hospitalization for a chest illness $(p<0.001)$. Studies describing the health burden associated with asthma in First Nations population are limited $[4,8]$ but report similar findings for healthcare usage.

Our findings for damp damage and visible mold support certain earlier findings by others $[27,28]$. Children participating in the 2005-2006 National Health and Nutrition Survey (NHANES III) were at increased risk for atopic asthma (total $\operatorname{IgE}>170 \mathrm{KU} / \mathrm{L}$ ) with a report of mildew odor in the home [27]. $\mathrm{Su}$ identified higher total and specific IgE levels in children with elevated fungal counts in their homes [28]. Evidence of positive associations between atopic asthma and damp housing are limited with a recent systematic review demonstrating that damp housing was more likely to be associated with non-atopic asthma rather than atopic asthma [12]. The inconsistencies in findings from studies could be partially due to the classification of dampness in studies or it could reflect the dynamic nature and problem of both the allergic and non-allergic agents of mold occurring simultaneously in damp housing environments [29]. Mycotoxin, volatile organic compounds (VOC's) or microbial agents such as endotoxin have been observed in moldy environments and could contribute to a non-atopic inflammatory response in children with asthma [30], whereas the proliferation of spores from mold species common to moldy domestic environments could produce an allergenic inflammatory response in children [27]. Objective evaluation of the broad array of microbial agents in damp homes at the time of study and over time would help to identify the specific microbial characteristics involved in the pathogenesis of atopic asthma phenotypes. While the kinds of microbial agents found in households may be important for developing immune responses, so might their concentration at certain critical times in the children's lives [10].

Over $40 \%$ of homes in the study had damage due to dampness. This is higher than that reported in recent regional cross-sectional studies with non-Aboriginal children using the same definitions of dampness (20.5\%) [23] and is very similar to findings from previous studies evaluating mold and dampness in First Nations reserve homes (44 to 54\%) [17,18]. Moisture continues to be a significant 
environmental problem in reserve homes and, as the findings from this study demonstrate, it may be a particular problem for those children with atopic asthma who live in such communities.

The associations we found between previous RRIs and non-atopic asthma support the findings from a recent review of predominant risk factors for non-atopic asthma [12]. Infectious respiratory incidences appear important for development of a specific allergic asthma phenotype. Recent evidence suggests that the relationship between respiratory infections and the occurrence of atopic or non-atopic asthma could be time specific where very early, severe respiratory infections can trigger asthma in atopic children, whereas chronic, low-level respiratory infections are more likely associated with development of non-atopic asthma [31].

In this study, natural gas as the main heating source was significantly higher in homes of children with non-atopic asthma. Similarly, $\mathrm{NO}_{2}$ levels in homes, many with gas stoves, was associated with non-atopic asthma in children participating in the NHANES III study [32]. The evidence for associations between natural gas heating or other indoor air pollutants and non-atopic asthma is preliminary and further studies should objectively measure indoor air quality and the relationship with asthma phenotypes.

\section{Limitations}

The cross-sectional nature of this study implies associative and non-causal relationships between asthma phenotypes and variables assessed. Further study to confirm causal associations are required. We used a questionnaire self-report of mold and dampness that may not accurately reflect actual damp housing conditions of homes [33]. Furthermore, it is possible that those who were more concerned about mold or water damage in their homes and who had a child with asthma or wheeze would be more likely to report its presence. Home owners have been shown to underestimate mold exposures in the home if they smoke or to over report household fungi exposure if they have allergies [33]. While the questions used to evaluate dampness and mold in the home were found to be consistent with unbiased housing inspections by others [34], objective characterization of the indoor environment for mold species, mycotoxins and endotoxin related biomarkers is still warranted.

We cannot exclude potential misclassification of asthma cases in the study, although a parental report of doctor-diagnosed asthma in questionnaires shows good correlation with observed physician-evaluated asthma [35]. We included a history of current wheeze in our definition, which could have misclassified some cases of wheeze as asthma. However, the usefulness of including current wheeze in the past 12 months as an indicator of asthma has been previously identified [36]. While atopy was based on objective measurement of allergy by SPT, asthma was based on parental report by questionnaire. To assess if there was misclassification of our definition of asthma that included wheeze in the past 12 months, we conducted a post hoc sensitivity analysis with the multinomial logistic regression models, with just children in the who had a report of doctor diagnosed asthma with or without atopy. The findings from the sensitivity analysis were consistent with the original analyses for all variables except for natural gas in the home, which was no longer associated with non-atopic asthma. We therefore conclude our main findings are fairly robust, excluding findings for natural gas heating which may be more likely associated with wheeze.

Other potential limitations of this study include the lower response rate to the study and the analysis of domestic and personal risk factors confined to those who consented to SPT for atopy $(n=280)$. According to the 2006 Canadian Census for these communities, younger children (age 5-9 years) in the study were proportionally represented while middle school children (10-14 years) were overrepresented and high school children (15-19 years) were underrepresented. Females were overrepresented by $5 \%$ in the study as well. Findings in this study should be viewed cautiously for older children and by sex [37]. When we compared those who participated in the screening for atopy $(n=280)$ with those who did not $(n=71)$, there were no significant differences between groups on the variables reported in Table 1 except for RRIs, whereby more children reporting a history of respiratory infections were more likely to participate in screening for atopy. 
We found no association between ETS exposure and asthma phenotypes, although ETS exposures evaluated in other studies do show associations with non-atopic asthma [12]. Non-significant findings between ETS and respiratory outcomes have been recorded in studies conducted in Aboriginal reserve communities [6,38]. The endemic nature of smoking in the studied communities may account for the non-significant findings for ETS and asthma. Prospective evaluation of the long-term effects of pervasive smoking exposures and lung health of Aboriginal children is still required.

\section{Conclusions}

In conclusion, we have demonstrated important associations between atopic asthma and damp and moldy domestic environments of First Nations children. As many of the children with asthma were non-atopic, objective evaluation of microbial contaminants and ventilation within these homes and their association with specific asthma phenotypes could assist in targeted asthma management and better environmental control.

Author Contributions: Conceptualization, D.C.R., J.A.L., S.K., S.A., J.A.D., P.P.; methodology, D.C.R., J.A.L., J.A.D., P.P.; software, C.P.K.; formal analysis, C.P.K.; data curation, D.C.R.; K.M., J.S. and J.M.; J.S. and J.M. served as "content experts" for the research project engaged in document review/editing and support during the data collection phases of the survey.; Writing-original draft preparation, reviewed the literature, reviewed the citations, and created the abstract and manuscript, D.C.R.; writing-review and editing, C.P.K., J.A.L., S.K., K.M., S.A., J.S., J.M., J.A.D., and P.P.; supervision, D.C.R., J.A.D., and P.P.; project administration, D.C.R., J.A.D., K.M., and P.P.; funding acquisition, S.A., J.A.D., and P.P. All authors have read and agreed to the published version of the manuscript.

Funding: This research was funded by a grant from the Canadian Institutes of Health Research "Assess, Redress, Re-assess: Addressing Disparities in Respiratory Health among First Nations People", grant number: CIHR MOP-246983-ABH-CCAA-11829-FRN-115096.

Acknowledgments: We are grateful for the contributions from Elders, community leaders and schools that facilitated this study, and most importantly, from all of the parents and children who took the time to participate. We would like to thank research nurses: Sarah Warrenton RN, BSN and Brooke Russell RN, BSN for their work with teachers, students and parents.

Conflicts of Interest: The authors declare no conflict of interest. The funders had no role in the design of the study; in the collection, analyses, or interpretation of data; in the writing of the manuscript, or in the decision to publish the results.

\section{References}

1. Statistics Canada. Aboriginal Peoples in Canada: First Nations People, Metis and Inuit: National Household Survey 2011; Statistics Canada: Ottawa, ON, Canada, 2013; p. 23. Available online: https://www12.statcan.gc.ca/nhsenm/2011/as-sa/99-011-x/99-011-x2011001-eng.pdf (accessed on 20 February 2020).

2. Rosychuk, R.J.; Voaklander, D.C.; Klassen, T.P.; Senthilselvan, A.; Marrie, T.J.; Rowe, B.H. Asthma presentations by children to emergency departments in a Canadian province: A population-based study. Pediatr. Pulmonol. 2010, 45, 985-992. [CrossRef] [PubMed]

3. Senthilselvan, A.; Lawson, J.; Rennie, D.C.; Dosman, J.A. Stabilization of an increasing trend in physician-diagnosed asthma prevalence in Saskatchewan, 1991 to 1998. Chest 2003, 124, 438-448. [CrossRef] [PubMed]

4. Crighton, E.J.; Wilson, K.; Senecal, S. The relationship between socio-economic and geographic factors and asthma among Canada's Aboriginal populations. Int. J. Circumpolar Health 2010, 69, 138-150. [CrossRef] [PubMed]

5. MacMillan, H.L.; Jamieson, E.; Walsh, C.; Boyle, M.; Crawford, A.; MacMillan, A. The health of Canada's Aboriginal children: Results from the First Nations and Inuit Regional Health Survey. Int. J. Circumpolar Health 2010, 69, 158-167. [CrossRef]

6. Senthilselvan, A.; Niruban, S.J.; King, M.; Majaesic, C.; Veugelers, P.; Laing, L.; Rowe, B.H. Prevalence and risk factors of asthma in First Nations children living on reserves in Canada. Can. J. Public Health 2015, 106, e483-e488. [CrossRef] 
7. Kovesi, T.; Gilbert, N.L.; Stocco, C.; Fugler, D.; Dales, R.E.; Guay, M.; Miller, D.J. Indoor air quality and the risk of lower respiratory tract infections in young Canadian Inuit children. CMAJ 2007, 177, 155-160. [CrossRef]

8. Chang, H.J.; Beach, J.; Senthilselvan, A. Prevalence and risk factors of asthma in off-reserve Aboriginal children and adults in Canada. Can. Respir. J. 2012, 19, e68-e74. [CrossRef]

9. Hemmelgarn, B.; Ernst, P. Airway function among Inuit primary school children in far northern Quebec. Am. J. Respir. Crit. Care Med. 1997, 156, 1870-1876. [CrossRef]

10. Noval Rivas, M.; Crother, T.R.; Arditi, M. The microbiome in asthma. Curr. Opin. Pediatr. 2016, $28,764-771$. [CrossRef]

11. Douwes, J.; Gibson, P.; Pekkanen, J.; Pearce, N. Non-eosinophilic asthma: Importance and possible mechanisms. Thorax 2002, 57, 643-648. [CrossRef]

12. Strina, A.; Barreto, M.L.; Cooper, P.J.; Rodrigues, L.C. Risk factors for non-atopic asthma/wheeze in children and adolescents: A systematic review. Emerg. Themes Epidemiol. 2014, 11, 5. [CrossRef] [PubMed]

13. Lawson, J.A.; Chu, L.M.; Rennie, D.C.; Hagel, L.; Karunanayake, C.P.; Pahwa, P.; Dosman, J.A. Prevalence, risk factors, and clinical outcomes of atopic and nonatopic asthma among rural children. Ann. Allergy Asthma Immunol. 2017, 118, 304-310. [CrossRef]

14. Fisk, W.J.; Lei-Gomez, Q.; Mendell, M.J. Meta-analyses of the associations of respiratory health effects with dampness and mold in homes. Indoor Air 2007, 17, 284-296. [CrossRef] [PubMed]

15. Quansah, R.; Jaakkola, M.S.; Hugg, T.T.; Heikkinen, S.A.; Jaakkola, J.J. Residential dampness and molds and the risk of developing asthma: A systematic review and meta-analysis. PLoS ONE 2012, 7, e47526. [CrossRef] [PubMed]

16. Berghout, J.; Miller, J.D.; Mazerolle, R.; O’Neill, L.; Wakelin, C.; Mackinnon, B.; Maybee, K.; Augustine, D.; Levi, C.A.; Levi, C.; et al. Indoor environmental quality in homes of asthmatic children on the Elsipogtog Reserve (NB), Canada. Int. J. Circumpolar Health 2005, 64, 77-85. [CrossRef] [PubMed]

17. Lawrence, R.; Martin, D. Moulds, moisture and microbial contamination of First Nations housing in British Columbia, Canada. Int. J. Circumpolar Health 2001, 60, 150-156. [PubMed]

18. Optis, M.; Shaw, K.; Stephenson, P.; Wild, P. Mold growth in on-reserve homes in Canada: The need for research, education, policy, and funding. J. Environ. Health 2012, 74, 14-21.

19. Karunanayake, C.P.; Albritton, W.; Rennie, D.C.; Lawson, J.A.; McCallum, L.; Gardipy, P.J.; Seeseequasis, J.; Naytowhow, A.; Hagel, L.; McMullin, K.; et al. Ear Infection and Its Associated Risk Factors in First Nations and Rural School-Aged Canadian Children. Int. J. Pediatr. 2016, 2016, 1523897. [CrossRef]

20. (AAAI) AAoAaI. Position paper: Allergen skin testing. J. Allergy Clin. Immunol. 1993, 92, 636-637. [CrossRef]

21. Arshad, S.H.; Tariq, S.M.; Matthews, S.; Hakim, E. Sensitization to common allergens and its association with allergic disorders at age 4 years: A whole population birth cohort study. Pediatrics 2001, 108, E33. [CrossRef]

22. Cole, T.J.; Lobstein, T. Extended international (IOTF) body mass index cut-offs for thinness, overweight and obesity. Pediatr. Obes. 2012, 7, 284-294. [CrossRef] [PubMed]

23. Barry, R.J.; Pickett, W.; Rennie, D.C.; Senthilselvan, A.; Cockcroft, D.W.; Lawson, J.A. Factors contributing to risks for pediatric asthma in rural Saskatchewan. Ann. Allergy Asthma Immunol. 2012, 109, 255-259. [CrossRef] [PubMed]

24. Rennie, D.C.; Karunanayake, C.P.; Chen, Y.; Nakagawa, K.; Pahwa, P.; Senthilselvan, A. CD14 gene variants and their importance for childhood croup, atopy, and asthma. Dis. Markers 2013, 35, 765-771. [CrossRef] [PubMed]

25. Chu, L.M.; Rennie, D.C.; Cockcroft, D.W.; Pahwa, P.; Dosman, J.; Hagel, L.; Karunanayake, C.P.; Pickett, W.L.; Lawson, J.A. Prevalence and determinants of atopy and allergic diseases among school-age children in rural Saskatchewan, Canada. Ann. Allergy Asthma Immunol. 2014, 113, 430-439. [CrossRef]

26. Brim, S.N.; Rudd, R.; Funk, R.H.; Callahan, D.B. Asthma prevalence among US children in underrepresented minority populations: American Indian/Alaska Native, Chinese, Filipino and Asian Indian. Pediatrics 2008, 122, e217. [CrossRef]

27. Sharpe, R.A.; Thornton, C.R.; Tyrrell, J.; Nikolaou, V.; Osborne, N.J. Variable risk of atopic disease due to indoor fungal exposure in NHANES 2005-2006. Clin. Exp. Allergy 2015, 45, 1566-1578. [CrossRef]

28. Su, H.J.; Wu, P.C.; Lei, H.Y.; Wang, J.Y. Domestic exposure to fungi and total serum IgE levels in asthmatic children. Mediat. Inflamm. 2005, 2005, 167-170. [CrossRef] 
29. Miller, J.D.; Dugandzic, R.; Frescura, A.M.; Salares, V. Indoor- and outdoor-derived contaminants in urban and rural homes in Ottawa, Ontario, Canada. J. Air Waste Manag. Assoc. 2007, 57, 297-302. [CrossRef]

30. Flamant-Hulin, M.; Annesi-Maesano, I.; Caillaud, D. Relationships between molds and asthma suggesting non-allergic mechanisms. A rural-urban comparison. Pediatr. Allergy Immunol. 2013, 24, 345-351. [CrossRef]

31. Holt, P.G.; Sly, P.D. Non-atopic intrinsic asthma and the 'family tree' of chronic respiratory disease syndromes. Clin. Exp. Allergy 2009, 39, 807-811. [CrossRef]

32. Kattan, M.; Gergen, P.J.; Eggleston, P.; Visness, C.M.; Mitchell, H.E. Health effects of indoor nitrogen dioxide and passive smoking on urban asthmatic children. J. Allergy Clin. Immunol. 2007, 120, 618-624. [CrossRef]

33. Dales, R.E.; Miller, D.; McMullen, E. Indoor air quality and health: Validity and determinants of reported home dampness and moulds. Int. J. Epidemiol. 1997, 26, 120-125. [CrossRef] [PubMed]

34. Andrae, S.; Axelson, O.; Bjorksten, B.; Fredriksson, M.; Kjellman, N.I. Symptoms of bronchial hyperreactivity and asthma in relation to environmental factors. Arch. Dis. Child. 1988, 63, 473-478. [CrossRef] [PubMed]

35. Ronmark, E.; Jonsson, E.; Platts-Mills, T.; Lundback, B. Different pattern of risk factors for atopic and nonatopic asthma among children-report from the Obstructive Lung Disease in Northern Sweden Study. Allergy 1999, 54, 926-935. [CrossRef] [PubMed]

36. Asher, I.; Pearce, N. Global burden of asthma among children. Int. J. Tuberc. Lung Dis. 2014, 18, 1269-1278. [CrossRef]

37. Statistics Canada. Census Profile. 2016 Census; Statistics Canada Catalogue no. 98-316-X2016001; Statistics Canada: Ottawa, ON, Canada, Released 29 November 2017. Available online: https://www12.statcan.gc.ca/ census-recensement/2016/dp-pd/prof/index.cfm?Lang=E (accessed on 20 March 2020).

38. Kovesi, T.; Creery, D.; Gilbert, N.L.; Dales, R.; Fugler, D.; Thompson, B.; Randhawa, N.; Miller, J.D. Indoor air quality risk factors for severe lower respiratory tract infections in Inuit infants in Baffin Region, Nunavut: a pilot study. Indoor Air 2006, 16, 266-275. [CrossRef] [PubMed]

(C) 2020 by the authors. Licensee MDPI, Basel, Switzerland. This article is an open access article distributed under the terms and conditions of the Creative Commons Attribution (CC BY) license (http://creativecommons.org/licenses/by/4.0/). 